\title{
Mountain lakes of Mont Avic Natural Park: ecological features and conservation issues
}

\author{
Rocco Tiberti, ${ }^{1,2^{*}}$ Francesco Buscaglia, ${ }^{2}$ Marco Armodi, ${ }^{3}$ Cristiana Callieri, ${ }^{1}$ Fabio Ribelli, ${ }^{2}$ Michela Rogora, ${ }^{1}$ \\ Gabriele Tartari, ${ }^{1}$ Massimo Bocca ${ }^{4}$
}

${ }^{1}$ CNR-IRSA Water Research Institute, Largo Tonolli 50, 28922 Verbania; ${ }^{2}$ Department of Earth and Environmental Sciences (DSTA), University of Pavia, Via Ferrata 9, 27100 Pavia; ${ }^{3}$ Department of Earth, Environment and Life Sciences (DISTAV), University of Genoa, Corso Europa 26, 16132 Genova; ${ }^{4}$ Mont Avic Natural Park Authority, Localita Fabbrica 164, 11020 Champdepraz (AO), Italy

\begin{abstract}
Mountain lakes provide some fundamental ecosystem services (i.e., water supply for drinking and energy production) and have an enormous aesthetic and conservation value. Ecological knowledge on mountain lakes, however, is still scarce and limited to a few geographical areas and mainly to abiotic features. To fill this gap, a limnological campaign was carried out on 19 lakes of the Mont Avic Natural Park (Aosta, Western Italian Alps). Bathymetric maps of the lakes are provided in this paper, as is data on the lakes' physical properties, chemistry, nano- and pico-plankton, zooplankton, littoral macroinvertebrates, amphibians and introduced fish. The aim of this study was to create a reference database of ecological data for the development of new studies and conservation measures/actions. To this end, ecological data are discussed from both a limnological and a conservation perspective, allowing for the identification of major threats affecting the lakes in the protected area. Despite local threats which include water exploitation, organic pollution, and introduced fish, water quality was good. Lake biota can however be affected by such threats, in particular introduced fish (Salmonidae and Cyprinidae), representing a challenging conservation problem.
\end{abstract}

\section{INTRODUCTION}

Mountain aquatic habitats provide essential ecosystem services such as drinking water supplies for much of the world (Williamson et al., 2008) and 16\% of its civil power generation $(67 \%$ of renewable energy sources; International Energy Agency, 2018). They also have tremendous aesthetic and conservation value (Kernan et al., 2009; Bellati et al., 2014), which can be affected by water abstraction and exploitation, as well as by various local and global threats. Sometimes, both the provision of essential services and environmental protection can be obtained simultaneously e.g., avoiding water

Corresponding author: rocco.tiberti@gmail.com

Key words: Lake morphometry; hydrochemistry; lake biota; protected areas; local threats; introduced fish.

Edited by: Francesca Bona, Dept. of Life Sciences and Systems Biology, University of Turin, Italy.

Received: 26 June 2019.

Accepted: 4 November 2019.

This work is licensed under a Creative Commons Attribution NonCommercial 4.0 License (CC BY-NC 4.0).

${ }^{\circ}$ Copyright: the Author(s), 2019

Licensee PAGEPress, Italy

J. Limnol., 2020; 79(1): 43-58

DOI: 10.4081/jlimnol.2019.1923 contamination in headwater systems keeps drinking water clean (New York City Department of Environmental Protection, 2010). More often than not however, conflict arises between conservation and utilitarian instances, as can be seen in the impacts caused by lake impoundment (Baxter, 1977) or the devastating consequences for native species and ecosystems caused by fish stocking that increases the recreational value of mountain aquatic habitats through sport fishing (Conniff, 2017; Tiberti et al., 2019a). In this complex context, one of the key tasks in mountain protected areas is to protect aquatic habitats by adopting the best possible conservation and management measures and by promoting the sustainable management of water resources.

Considering aquatic habitats, mountain lakes can be affected by several local threats, such as hydroelectric exploitation, introduced fish, and point-source organic pollution from free ranging livestock and touristic infrastructures (Derlet et al., 2012; Tiberti et al., 2014a). Their high sensitivity to any physical, chemical and biological disturbance, has led to high mountain lakes being considered "early response" indicators of global change, which increases their scientific and societal value (Williamson et al., 2008). For example, high mountain lakes have been used as sentinels of climate change, atmospheric deposition and air pollutants (Rogora et al., 2008).

Ecological data on mountain lakes are therefore very useful in the identification and quantification of both local and global threats as well as in the monitoring of anthropogenic impacts, acting on both a regional and global scale. Data from mountain protected areas in 
particular may contribute to inform conservation policies and plan possible restoration measures (Boggero et al., 2019). However, ecological data on mountain lakes are still fragmentary, i.e., limited to a few areas or to single/few components of the ecosystem (e.g., hydrochemistry, single taxonomic groups).

In the present study we report the results of a limnological campaign performed in 2017-2018 on several ecological features of the mountain lakes in the protected area of Mont Avic Natural Park (MANP, Western Italian Alps), with the aim of creating a reference database of ecological data to i) expand current knowledge of mountain lake ecosystems; ii) identify the main threats affecting the lakes in the protected area; iii) support new studies and conservation projects with quantitative data. This is the first comprehensive limnological study within the protected area, as previous information was limited to the hydrochemistry of a few lakes.

\section{METHODS}

\section{Study area}

Mont Avic Natural Park (MANP, Western Italian Alps; established in 1989) stretches over 5747 hectares in the Chalamy (municipality of Champdepraz) and Champorcher (municipality of Champorcher) valleys. MANP has been declared a Special Conservation Site (IT1202000 - Parco Naturale Mont Avic) and is included in the Special Protection Area IT1202020 - Mont Avic and Mont Emilius of the EU Natura 2000 Network (Council of the European Communities, 1979, 1992). The protected area shows a wide altitudinal range (from 1000 to 3185 $\mathrm{m}$ asl, Mont Glacier) and a typical Alpine climate, with relatively low levels of precipitation (on average 800$1200 \mathrm{~mm} \mathrm{year}^{-1}$ ). The area includes over 40 standing water bodies and several peat-bogs.

The present study involves 19 lakes (Tab. 1), representing all the larger water bodies $(>0.5 \mathrm{ha})$ of the protected area. Most sites are small natural lakes with a glacial origin, but L. Miserin and Gran Lac have been impacted by the presence of hydroelectric infrastructures. L. Miserin was enlarged by the construction of a $6.2 \mathrm{~m}$ high dam and connected to hydroelectric power plant by penstocks, while water runoff from Gran Lac is regulated by a valve positioned at its bottom, which can almost completely drain the lake. The lakes are situated between 1802 and $2704 \mathrm{~m}$ asl (Tab. 1), encompassing a large gradient of microclimatic conditions. Vegetation cover surrounding the lakes includes forests of mountain pine Pinus montana uncinata, larch Larix decidua and Scots pine Pinus sylvestris, subalpine pastures and alpine prairies. The highest lakes are mainly surrounded by bare rock with very sparse herbaceous vegetation. Glaciers are

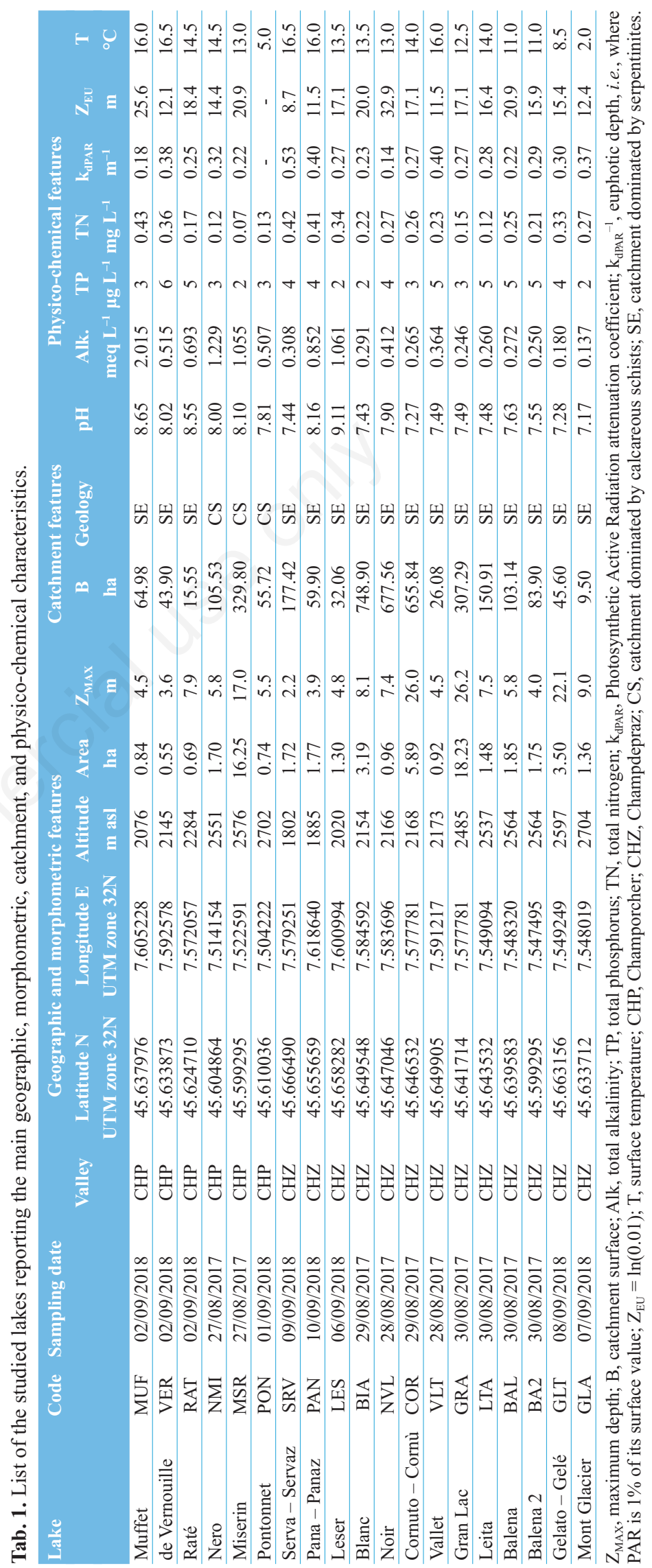


virtually absent from the study area; only one lake, L. Mont Glacier, is fed by permafrost thawing emerging from a small rock-glacier, i.e., tongue-shaped bodies of frozen debris with interstitial ice cement. Catchment geology is dominated by calcareous schists in the upper part of the Champorcher valley and serpentinites in the rest of the Park, which includes the whole Chalamy Valley (ISPRA, 2010). Human activities in the lake catchments include the presence of tourists, a few mountain huts (near L. Blanc, Muffet and Miserin) and livestock. Livestock grazing (herds of sheep and cows) around the lakes affect most of the study lakes with the exception of those situated in completely forested areas (L. Leser and Panaz), those at higher altitudes (L. Gelato and Mont Glacier), or those protected by exclusion fences (L. Vallet).

\section{Sampling and analytical methods}

\section{Study period}

The present study was completed between June 2017 and September 2019. Lake bathymetries were taken during the 2017-2018 ice-free seasons. Water samples for chemical and nano- and pico-plankton analyses and zooplankton and macroinvertebrate samples were collected once per lake in the late summer (between $27^{\text {th }}$ Aug - $9^{\text {th }}$ Sep, 2017-2019) to reduce as much as possible the effects of seasonal variations affecting mountain lakes and to observe the mature stages of these highly dynamic planktic communities (Tiberti et al., 2013). Fish and amphibian populations were surveyed from one to seven times per lake during the whole study period.

\section{Geographic, morphometric and catchment features}

Lake coordinates (Lat N, Long E) and altitudes (Alt) were obtained from IGN (Istituto Geografico Nazionale) cartography. Bathymetric maps and maximum depths $\left(\mathrm{Z}_{\mathrm{MAX}}\right)$ were obtained through low-resolution bathymetric surveys, i.e., lake depth was measured from an inflatable dinghy at various points uniformly distributed on the lake surface. We used high resolution satellite images from Google Maps to measure lake area (A) and perimeter (L), and the GRASS plugins "r.watershed" and "r.wateroutlet" to measure the lake catchment area (B). Other morphological features (volume-V, coastline development-DL, relative depth- $Z_{R}$, mean depth- $Z_{M}$, volume development-DV, watershed:lake area ratio-BA) were calculated following Wetzel and Likens (1991). All cartographic analyses were carried out using QuantumGIS (QGIS version 2.18.24).

\section{Physical parameters}

Surface temperature and vertical profiles of light intensity were measured in situ at the point of maximum depth. Vertical profiles of light intensity were measured throughout the water column at 1 or $0.5 \mathrm{~m}$ intervals $(0.5$ $\mathrm{m}$ in very shallow lakes with $<4 \mathrm{~m}$ maximum depth), using a light meter (LI-COR LI-250) with a submersible sensor for Photosynthetically Active Radiation (PAR, 400-700 $\mathrm{nm}$ ), from one centimetre below the water surface to the bottom. The vertical extinction coefficient ( $k_{d}$ PAR) was estimated for each lake by fitting an exponential curve of the percent PAR reaching each sampling depth, assuming the mean of the surface measurements to be $100 \%$. The PAR profiles were measured in constant lighting conditions (either full sunlight or persistent cloud cover without bright spells or drifting cloud patches).

\section{Water chemistry}

Composite water samples (1 L) for chemical analyses were collected at the point of maximum depth of each lake over the whole water column with a horizontal $2.2 \mathrm{~L}$ Van Dorn bottle and stored in darkness at $4^{\circ} \mathrm{C}$ until the analysis. Composite samples were obtained by mixing equal volumes of water collected at regular depth intervals, i.e., three depths (surface, mid-depth, and bottom) for shallow lakes ( $<10 \mathrm{~m}$ deep) and five depths for deep lakes ( $>10 \mathrm{~m}$ deep). Samples were analyzed at the water chemistry laboratory of CNR-IRSA in Verbania following standard methods (APHA, AWWA, WEF, 2005) and considering the following variables: $\mathrm{pH}$, conductivity (EC) (Radiometer ION450), alkalinity (alk) (Gran titration), $\mathrm{NH}_{4}^{+}$, total phosphorus (TP), total nitrogen (TN) (UV-VIS spectrophotometer SAFAS UV $\mathrm{mc} 2$ ), reactive silica $(\mathrm{Si})$ (continuous flow analysis), main anions $\left(\mathrm{Cl}^{-}, \mathrm{SO}_{4}{ }^{2-}, \mathrm{NO}_{3}^{-}\right)$and cations $\left(\mathrm{Ca}^{2+}, \mathrm{Mg}^{2+}, \mathrm{Na}^{+}\right.$, $\mathrm{K}^{+}$) (ion chromatography after filtration on $0.8-\mu \mathrm{m}$ pore size filters; ion analyzer Dionex series ICS3000) and total organic carbon (TOC) (catalytic combustion with a Skalar Formacs series TOC/TN Analyzer). Organic nitrogen (ON) concentrations were calculated from the difference between TN and inorganic nitrogen $\left(\mathrm{IN}=\mathrm{NO}_{3}{ }^{-}+\mathrm{NH}_{4}{ }^{+}\right)$ concentrations. Both internal and external quality controls were adopted in the laboratory, including the regular use of control charts, checking of ion balance, comparison of measured and calculated conductivity and participation in proficiency tests.

\section{Autotrophic nanoplankton and picoplankton}

Water samples for autotrophic nanoplankton (size range $2-20 \mu \mathrm{m}$ ) and picoplankton (size range: 0.2 and 2 $\mu \mathrm{m})$ enumeration were collected near the lake surface and bottom at the point of maximum depth using a Van Dorn bottle. Water samples $(10 \mathrm{~mL})$ were preserved in $2 \%$ formaldehyde solution. Phycoerythrin-containing picocyanobacteria (PE i.e., genus Synechococcus), 
phycocyanin-containing picocyanobacteria (PC), and heterotrophic prokaryotes (HPRO) were enumerated by flow cytometry (Flow Cytometer Accuri C6, Becton Dickinson, Oxford, UK) as well as the autotrophic eukaryotic autotrophic nanoplankton (EUK). However, it must be noted that flow cytometer is not suitable for enumerating large-sized and colony-forming algae; EUK enumeration data should be therefore considered with caution as large errors could be linked to the method used. The flow cytometer was equipped with a $20 \mathrm{~mW} 488 \mathrm{~nm}$ Solid State Blue Laser and a $14.7 \mathrm{~mW} 640 \mathrm{~nm}$ Diode Red Laser. The BD Accuri C6 software was used for the semiautomatic distinction of the different planktic groups.

The light scattering signals (forward FSC and side light scatter SSC), green fluorescence (FL1 channel $=$ $533 / 30 \mathrm{~nm}$ ), orange fluorescence (FL2 channel $=585 / 40$ $\mathrm{nm}$ ) and red fluorescence (FL3 channel $>670 \mathrm{~nm}$ and FL4 channel $675 / 25 \mathrm{~nm}$ ) were acquired to discriminate the distinct microbial groups. For PE, PC and EUK, we set the thresholds of 7000 for FSC-H and 1500 for FL4-H. Density plot of FL2-H vs FL3-H allowed for the optimal distinction and absolute counting of each plankton category (Callieri et al., 2016).

Total prokaryotes were counted by staining with SYBR Green I (1:10000 final concentration; Molecular Probes, Invitrogen). Density plots of FSC vs FL1 allowed for optimal distinction between the stained microbial cells and background noise, with a threshold value of 1000 applied on the FL1-H channel and 500 on FSC-H channel. We subtracted from the total prokaryotes the autotrophic fraction to reach the HPRO events $\mathrm{mL}^{-1}$. All data were acquired at a pre-set flow rate of $35 \mathrm{~mL} \mathrm{~min}^{-1}$, in order to keep the number of total events below 1000 per second.

To calibrate the automatic data acquisition and to validate the cell counts, random samples were checked at the epifluorescence microscope (Zeiss Axioplan, Germany) equipped with a HBO $100 \mathrm{~W}$ lamp, a Neofluar $100 \times$ objective, $1.25 \times$ additional magnification and filter sets for UV (G365, FT395, LP420), blue (BP450-490, FT510, LP520) and green light excitation (LP510-560, FT580, LP590). For prokaryotes $0.5-1.0 \mathrm{~mL}$ of DAPI (5', 6-diamino-2-phenylindole, final concentration $0.1 \mu \mathrm{g}$ $\mathrm{mL}^{-1}$; Porter and Feig, 1980) stained subsamples were filtered and counted with the UV filter set. For PE and PC, blue and green filters were used.

\section{Zooplankton}

Zooplankton was sampled in late summer (Aug-Sep) to observe the mature stages of these highly dynamic communities inhabiting mountain lakes (Tiberti et al., 2013). Samples were collected at the deepest point of each lake by taking vertical tows from the bottom to the surface with a conical plankton net $(40 \mathrm{~cm}$ diameter, $50 \mu \mathrm{m}$ mesh). Sample fixation in $70 \%$ ethanol was carried out in the field. Specimens were identified to the species level following Braioni and Gelmini (1983), Stella (1984), Margaritora (1985) and Einsle (1996). Coarser taxonomic levels indicating a group of species (gr.) or the genus, have been used in the case of uncertain taxonomy (e.g., Keratella gr. quadrata) or when the specific identification was not possible because of morphological deformations due to the conservative medium (e.g., Synchaeta sp., Ascomorpha sp.). Zooplankton was enumerated using a closed counting chamber under a binocular dissecting microscope (Olympus CH-BI45-3) at $40 \times$ in order to obtain density data (individuals $\mathrm{m}^{-3}$; Edmondson and Winberg, 1971).

\section{Macroinvertebrates}

All shore-accessible habitats were sampled for semiquantitative macroinvertebrate estimates. Three littoral habitats were chosen according to clast diameter: sand shores (clast diameter $<2 \mathrm{~mm}$ ), gravel shores $(2 \mathrm{~mm}$ $\leq$ clast $<64 \mathrm{~mm}$ ), and stony shores (clast $\geq 64 \mathrm{~mm}$ ). In each of these habitats, ten sweeps, each about $1 \mathrm{~m}$ long, were conducted with a standard d-frame net (mouth, 259 $20 \mathrm{~cm}$; mesh $0.5 \mathrm{~mm}$ ) following Knapp et al. (2001). If some microhabitats were not accessible, the missing sweeps were equally divided between the remaining microhabitats. Benthic macroinvertebrates were separated from detritus and sediments in the field and preserved in $70 \%$ ethanol. Macroinvertebrates were identified to a family or genus level following Campaioli et al., (1994).

\section{Visual Encounter Survey for amphibians and introduced fish}

Visual Encounter Surveys (VES; Crump and Scott, 1994) were performed 1-7 times per lake by walking along the accessible parts of the perimeter of each lake to monitor the presence and relative abundance of amphibians and introduced fish:

- Rana temporaria is the only amphibian species inhabiting the high-altitude lakes of MANP; the number of egg masses, tadpoles, froglets (i.e., freshly metamorphosed individuals) and adult individuals of $R$. temporaria was recorded. The presence of eggs, larvae or froglets indicates that reproduction occurred.

- The number of observed salmonid fish was recorded, while Cyprinidae (i.e., minnow Phoxinus sp. and vairone Telestes muticellus) were assigned to one of five abundance categories based on gross counting $(\mathrm{N})$ estimates $(\mathrm{N}=0 ; 1 \leq \mathrm{N} \leq 10 ; 10<\mathrm{N} \leq 100 ; 100<\mathrm{N}$ $\leq 1000 ; \mathrm{N}>1000$ ), because their enumeration was impossible when populations were very large. When possible, fish species identification was recorded, but species identification was easier by close observation of captured fish (see next paragraph). 


\section{Introduced fish: present state and stocking history}

Multi-mesh gillnets $(36 \mathrm{~m}$ long $\times 1.8 \mathrm{~m}$ high, divided into six panels with increasing mesh sizes: 10.0, 12.5, $18.5,25.0,33.0,38.0 \mathrm{~mm})$ and fyke nets $(0.5 \mathrm{~m}$ wide $\times$ $0.4 \mathrm{~m}$ high D-shaped mouth, $4 \mathrm{~mm}$ mesh size with a $2 \mathrm{~m}$ long central wing or lead) were used to target Salmonidae and Cyprinidae respectively. Captured fish were identified to the species level and capture data were used to calculate a relative density index, i.e., Capture Per Unit Effort (CPUE) expressed as fish number per sampling unit per hour. Sampling units are one gillnet or one fyke net for Salmonidae and Cyprinidae respectively; 1-2 gillnets were placed in the central part of the lakes with the smallest mesh size panels placed close to shore and were left for 2-72 h; 1-6 fyke nets were placed with their mouths facing the shoreline in the littoral area for 3-31.5 h. Between July 2017 and September 2019, we performed 1-3 gill-netting and 1-7 fyke-netting sessions in all the study lakes excepting L. Servaz, Vallet and Mont Glacier. Of these three lakes, fish are certainly absent at least from L. Vallet and Mont Glacier. Fish were never observed and are therefore absent in L. Vallet, which is well monitored by MANP surveillance personnel because of the presence of a family group of tufted duck Aythya fuligula (L. 1758), whose presence made gill netting inappropriate due to its capacity for causing harm to the ducks (Tiberti et al., 2019a). Similarly, fish are certainly absent from L. Mont Glacier because of its extreme thermal properties and because there are no records of fish introduction in this lake.

Fish samples were compared with recent fishery (2012-2017) and fish stocking public data (2001-2018) from the local fishery management authority (Consorzio Pesca VDA). Fishery data could provide up-to-date information on current fishery conditions (i.e., catch by species), while stocking data has enabled us to reconstruct recent (i.e., last 20 years) fish stocking history.

\section{RESULTS}

\section{Abiotic features}

Morphometric data are summarized in Tab. 1 and Figs. 1-3, but see Supplementary "Ecological Data" for detailed data. Natural water level fluctuations can alter lake morphology, but they are usually absent or moderate in the study lakes, i.e., 0.2-1 m in L. Blanc, Cornù, and de Vernouille, and $>1 \mathrm{~m}$ in L. Servaz. Artificial water level variations of L. Miserin and Gran Lac can however be larger. Tributaries are often visible only at the beginning of summer, when the lakes are abundantly supplied by melting snow.

The study lakes are characterized by low ionic content, oligotrophic-ultraoligotrophic conditions and cold, clear water (Tab. 1; Supplementary "Ecological Data"). The range of variation of total alkalinity $(180-2015 \mu \mathrm{eq} \mathrm{L}-1)$ and $\mathrm{pH}(7.17-9.15)$ is typical of mountain lakes situated on soluble rocks such as calcareous schists and serpentinites. Among ions, the prevailing contribution was usually given by $\mathrm{Ca}^{2+}$ among cations and $\mathrm{HCO}_{3}^{-}$(bicarbonate, represented by alkalinity) or $\mathrm{SO}_{4}{ }^{2-}$ among anions, the former dominating in the lakes situated on a calcareous substrate and the latter in the lakes situated on a serpentinite substrate. Nutrient content (TP, TN, TOC) was generally

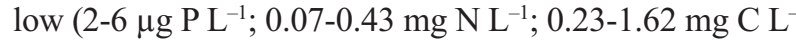
${ }^{1}$ respectively). Nitrate accounted for most (mean $\pm \mathrm{SD}=$ $54 \pm 25 \%$ ) of the TN, but ON often accounted for a substantial part of the TN (e.g., L. Vallet and Leita). TN:TP ratio ranged from 34 to 170 in weight. PAR attenuation coefficients (i.e., water transparency) ranged between 0.14 $\left(D_{\mathrm{EU}}=32.9 \mathrm{~m}\right.$; L. Nero $)$ and $0.53 \mathrm{~m}^{-1}\left(\mathrm{D}_{\mathrm{EU}}=8.7 \mathrm{~m}\right.$; L. Servaz) and only the deeper L. Cornuto, Gran Lac, and Gelato showed aphotic conditions at the bottom on the sampling dates (Tab. 1). Surface temperature did not once exceed $16^{\circ} \mathrm{C}$ at the time of sampling.

\section{Native biota and introduced fish}

Planktic pico-prokaryotes were represented by heterotrophic prokaryotes (HPRO) and picocyanobacteria (PC and PE) in all study lakes. Their abundance was highly variable among lakes (see Supplementary Material "Ecological Data"; Fig. 4). HPRO abundance ranged between $1.3 \times 10^{4}(\mathrm{~L}$. Gran Mont Glacier near the surface) and $1.2 \times 10^{6}$ cells $\mathrm{mL}^{-1}$ (L. Leser near the bottom). The autotrophic fraction of the prokaryotic community (PC and $\mathrm{PE}$ ) showed markedly lower abundances than HPRO, and a large variability, e.g., from very low densities in L. Balena 2 (9 PE cells $\mathrm{mL}^{-1}$ ) to the maximum abundance in $\mathrm{L}$. de Vernouille $\left(1.0 \times 10^{4} \mathrm{PC}\right.$ cells $\left.\mathrm{mL}^{-1}\right)$. Autotrophic nanoplankton densities (EUK) were similar to picocyanobacteria ranging from 44 (L. Mont Glacier) to $2.4 \times 10^{4}$ (L. de Vernouille) cells $\mathrm{mL}^{-1}$. Microplankton densities were generally higher near the bottom than close to the surface. Data from L. Blanc are not available because samples were damaged in transit.

A total of 20 different taxonomic groups were recorded in the zooplankton communities, which were composed of cladocerans, copepods, rotifers and the aquatic larvae of Chaoborus sp. (Diptera, Insecta; found only in L. Vallet) (see Supplementary "Ecological Data" for a detailed taxonomic list and densities). Overall, Keratella quadrata, Polyarthra sp., Daphnia gr. longispina, Arctodiaptomus alpinus, and Cyclops abyssorum were the most common and abundant taxa. Zooplanktonic richness varied between 4 and 9 taxa per lake. The density of large zooplankton taxa (>1 mm; i.e., Daphnia sp., Arctodiaptomus alpinus, and Cyclops abyssorum) was highly variable, whilst small 
zooplankton taxa were mainly represented by rotifers with a few small crustaceans living at low densities (Fig. 5). In L. de Vernouille, Panaz, Gran Lac and Leita, large zooplankton taxa were either absent or at very low densities $\left(<100\right.$ ind $\left.\mathrm{m}^{-3}\right)$.

In the littoral area, a total of 18 macroinvertebrate taxa were found, with chironomid larvae as the most abundant group (see Supplementary "Ecological Data"). The macroinvertebrate communities were composed of 1-14 taxa; L. Mont Glacier presented the most simplified community, composed exclusively of chironomid larvae.

Rana temporaria was detected by VES in 12 out of the 19 lakes (Tab. S1). It was absent in L. de Vernouille, Pontonnet, Cornù, Gran Lac, Balena 2, Gelato and Mont Glacier, while in L. Miserin, Panaz, and Leita only adult individuals (i.e., with no signs of reproductions) were recorded. Fish detection by VES enabled us to detect the presence of fish in 14 out of the 19 lakes (Tab. S1): Cyprinidae in six lakes (de Vernouille, Miserin, Panaz, Gran Lac, Balena, Balena 2), Salmonidae in four lakes (Muffet, Nero, Leser, and Gelato), and both fish families in four lakes (Blanc, Noir, Cornù, Leita). When present, Cyprinidae were usually very abundant with hundreds or thousands of observed individuals, while Salmonidae were usually less visible. Direct observation during the VES enabled us to identify the fish inhabiting L. Gelato as Salvelinus alpinus and the fish inhabiting L. Leser as Salmo trutta, although it was not possible to identify any of the salmonid fish inhabiting L. Cornù.

Fishing sessions enabled us to record the presence of

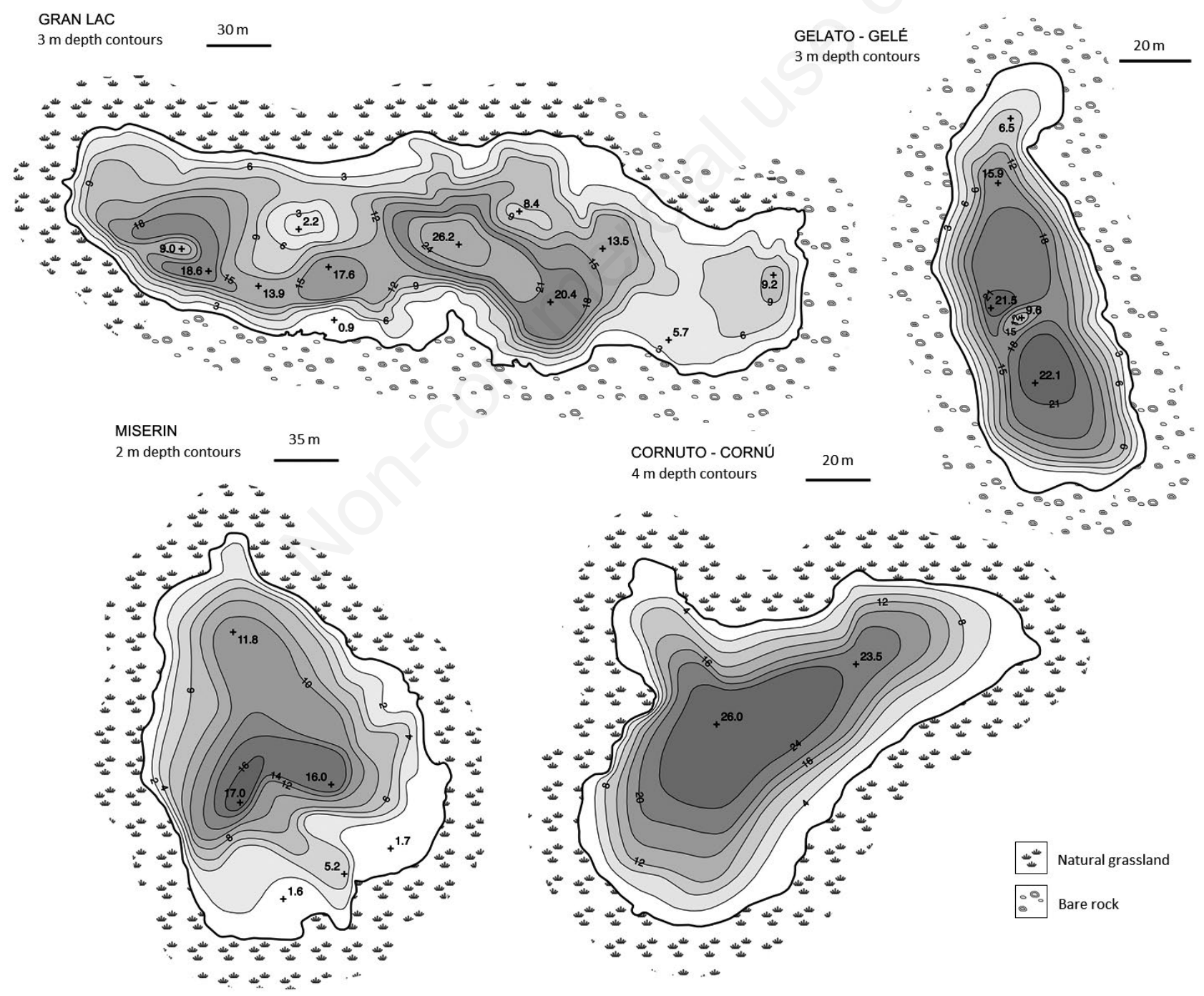

Fig. 1. Bathymetry of Lakes Panaz, Balena, de Vernouille, Balena 2, Leser-Lese, Servaz-Serva, Muffet, Pontonnet, Glacier, and NeroNoir (Mont Avic Natural Park, Western Italian Alps). 

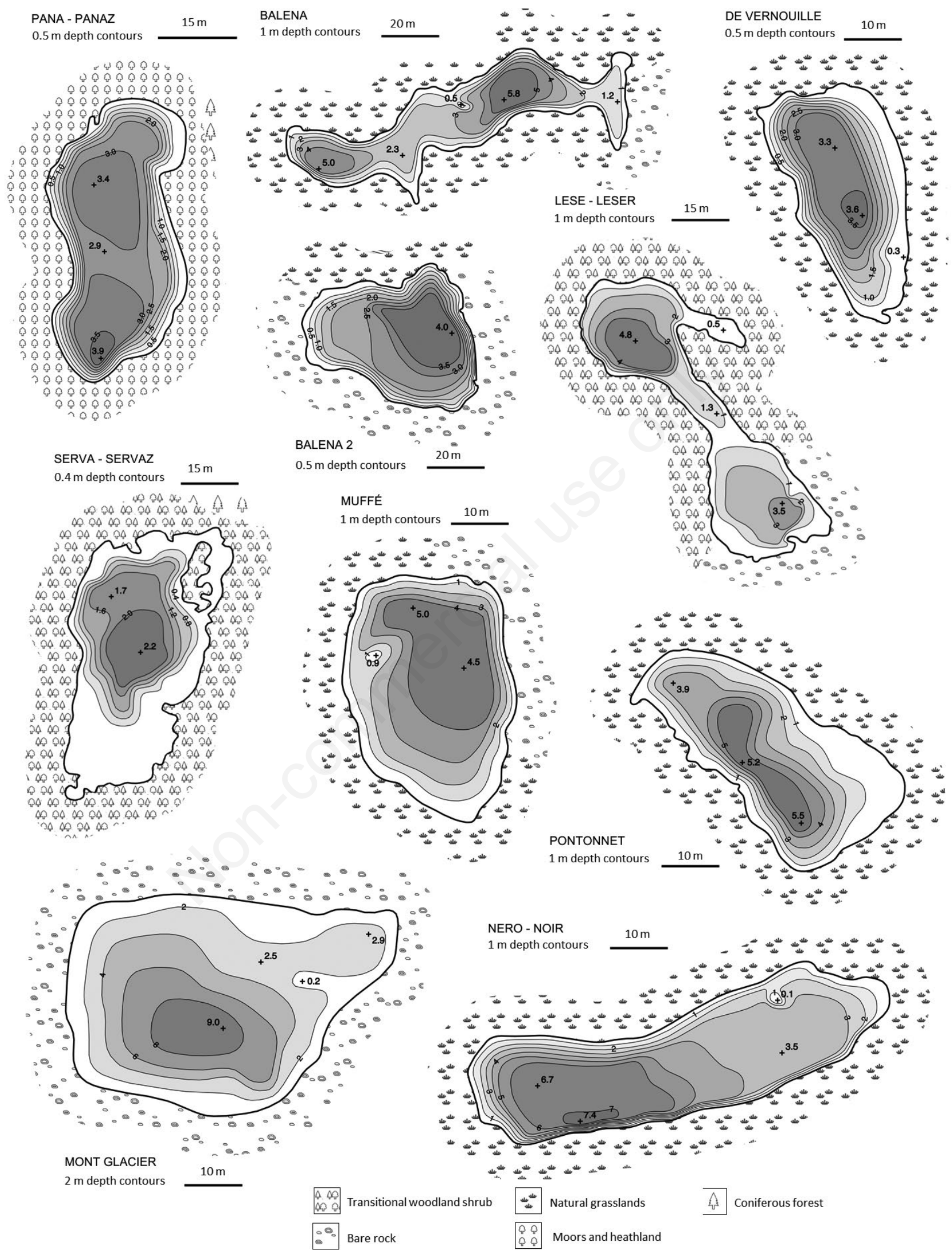

Fig. 2. Bathymetry of Lakes Gran Lac-Gran Lago, Gelato, Miserin, and Cornù (Mont Avic Natural Park, Western Italian Alps). 
four fish species in the protected area: alpine charr Salvelinus alpinus (in L. Miserin, Nero, Noir, Gelato), brown trout Salmo trutta (in L. Blanc, Muffet, Leita), minnow Phoxinus sp. (in L. de Vernouille, Miserin, Cornù, Gran Lac, Leita, Balena) and vairone Telestes muticellus (in L. Panaz). The presence of worm-like markings on the back of some Salvelinus alpinus -a distinctive phenotypic trait of brook trout Salvelinus fontinalis (Mitchill, 1815)- indicates that some of the captured fish could actually be $S$. alpinus $\times S$. fontinalis hybrids. Despite the relatively large fishing effort (more than $72 \mathrm{~h}$ of continuous gillnetting in L. Cornù and Blanc), very few salmonid fish were captured $(\mathrm{N}=30)$ in the fishing apparatus, whereas a much larger number of Cyprinidae ( $\mathrm{N}=8423)$ were captured both in the gillnets and in the fyke nets (Tab. S2). Fish densities were variable for both Salmonidae and Cyprinidae (Fig. 6), with a singularly high density of Phoxinus sp. in L. de Vernouille.

Compared to VES, fishing sessions were unable to detect neither the presence of Salmonidae in L. Blanc, Cornù or Leser, nor the presence of Cyprinidae in L. Balena 2. Compared to fishery data from the Consorzio Pesca VDA, our sampling efforts enabled us to describe the distribution of Cyprinidae, which are not included in the fishery dataset. Fishery data confirmed the presence of Salmo trutta and Salvelinus sp. in the MANP and added rainbow trout Oncorhyncus mykiss to the list of fish which are probably present in the protected area. However, the absence of Oncorhyncus mykiss from our surveys suggests that this species may be unable to form stable populations in the study area. In addition, fishery data extend the presence of Salmonidae to some lakes (i.e., de Vernouille, Raté, Pontonnet, Servaz, Panaz, Gran Lac, Balena, Balena 2) where they were not detected during our surveys (VES and sampling), suggesting that the number of species in each lake could be larger than what was expected based on our surveys. According to the fishery data, Salmonidae have recently been present in all the lakes in the MANP excepting L. Vallet and Mont Glacier. Fishery data from the Consorzio Pesca VDA also provide a description of the recent (2000-2018) stocking history of the lakes of MANP (Tab. S3). The last authorized fish introductions date back to 2014. Only brown trout has officially been stocked in the last ten years, whilst Salvelinus alpinus and Oncorhyncus mykiss were also stocked in several lakes in the period 2000-2009 (Tab. S3).
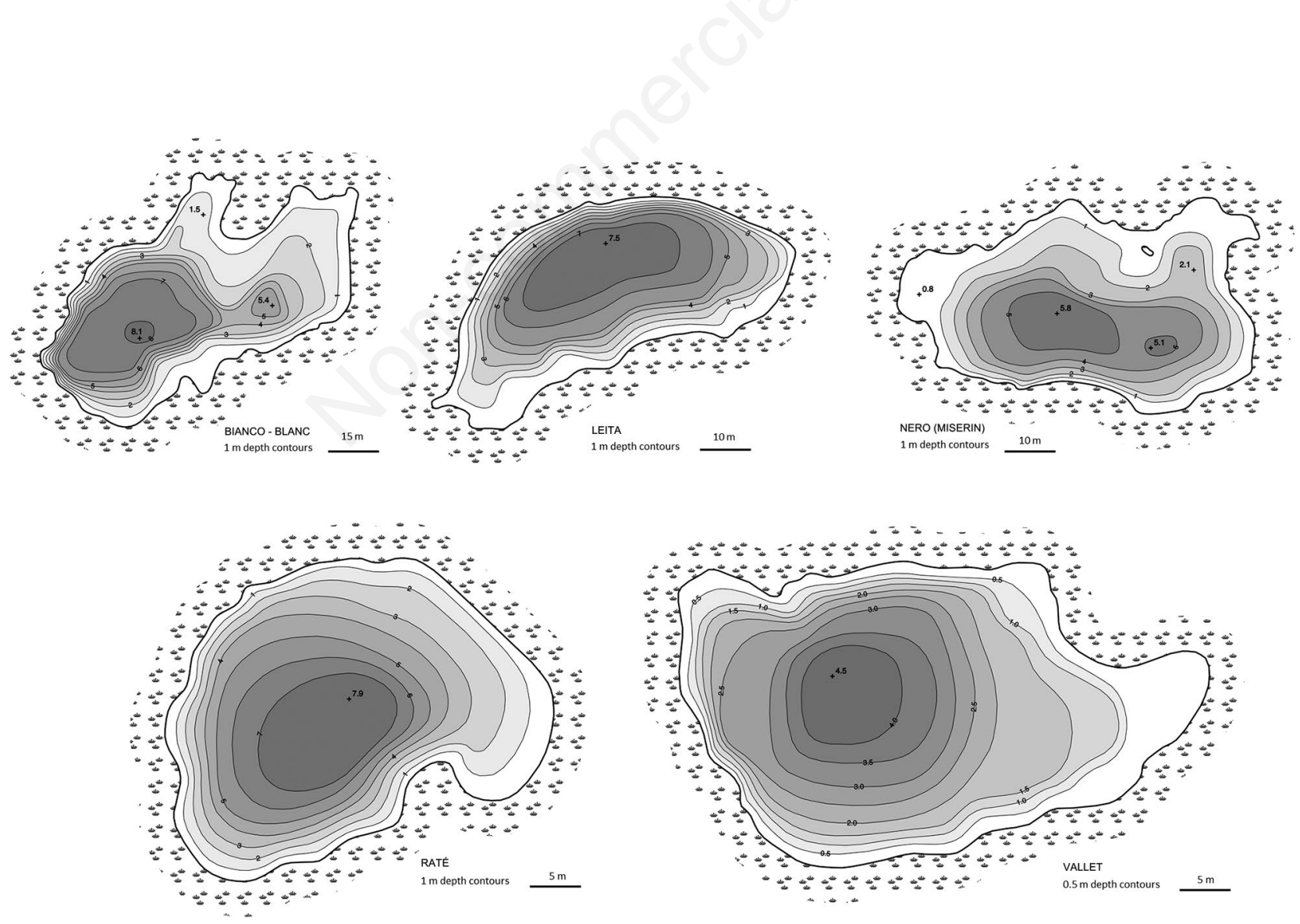

Fig. 3. Bathymetry of Lakes Bianco-Blanc, Leita, Nero, Raté, and Vallet (Mont Avic Natural Park, Western Italian Alps). 


\section{DISCUSSION}

\section{The abiotic environment}

The morphometric parameters of the studied lakes are in the typical range of variation of high mountain Alpine lakes (Giussani et al., 1986; Cantonati et al., 2002; Cantonati and Lazzara, 2006; Tiberti et al., 2010, 2019b), which can be attributed to their common glacial origin (Margalef, 1983). Lake temperatures are consistent with the values commonly observed in typical cold and oligotrophic mountain lakes (Margalef, 1983). Surface temperature variation among the lakes follows the altitudinal climatic gradient relatively well, with the lowest temperatures recorded in the lakes situated at higher altitudes (Tab. 1). Relatively low transparency values (i.e., $K_{d P A R}>0.35$ ) can be attributed to higher levels of suspended organic matter of some shallow lakes situated at lower altitudes (de Vernouille, Servaz, Panaz,
Vallet), whilst turbidity in L. Mont Glacier is induced by suspended mineral particles carried by glacial runoff.

The chemical composition of mountain lakes depends on the interplay of several environmental variables and in particular on catchment geology (Rogora et al., 2008; Tiberti et al., 2019b). The chemical properties of the lakes of the MANP are consistent with the values commonly recorded in mountain lakes across the temperate regions, i.e., low ionic and nutrient content (Margalef, 1983; Camarero et al., 2009). Despite the low solute content, the lakes are well protected against acidification (i.e., total alkalinity $>200 \mu \mathrm{eq} \mathrm{L}{ }^{-1}$; Marchetto et al., 1995). The lakes have a high TN:TP ratio (range: 24-170), which indicates phosphorus limitation of phytoplankton growth according to Redfield's ratio. TP concentrations are similar to the values recorded from other mountain regions and indicate oligotrophic and ultra-oligotrophic conditions (Marchetto et al., 1994, 1995; Kopáček et al., 2000; Toro et al., 2006;
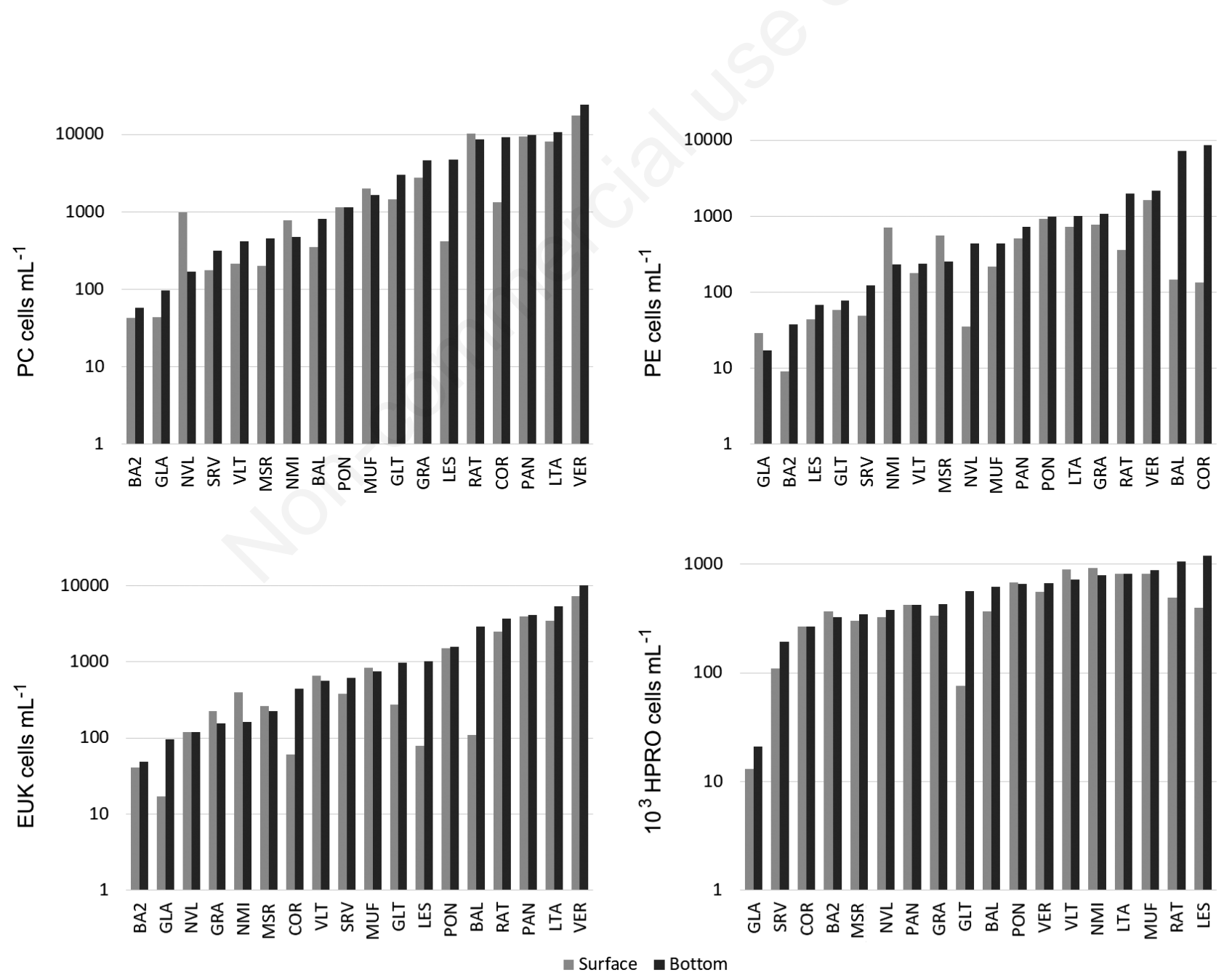

Fig. 4. Nano- and pico-plankton densities at lakes' surface and bottom. EUK, eukaryotic phytoplankton; PE, phycoerythrin-containing picocyanobacteria (i.e., genus Synechococcus); PC, phycocyanin-containing picocyanobacteria; HPRO, heterotrophic prokaryotes; lake codes from Tab. 1. 
Rogora et al., 2008; Tiberti et al., 2019b). In most lakes in the MANP, nitrate concentration accounts for a substantial part of TN, indicating a possible effect of longrange transportation of nitrogen compounds, as has already been observed in the study area by Cremonese $e t$ al. (2008b). As a matter of fact, this is a common finding across the whole Alpine region, especially in the Central and Western Alps, which are affected by the long-range transportation of pollutants from high emission sources located in lowland regions (e.g., the Plain of River Po; Rogora et al., 2008).

\section{Native biota}

\section{Nano and picoplankton}

The densities of pico- and nano- plankton in MANP
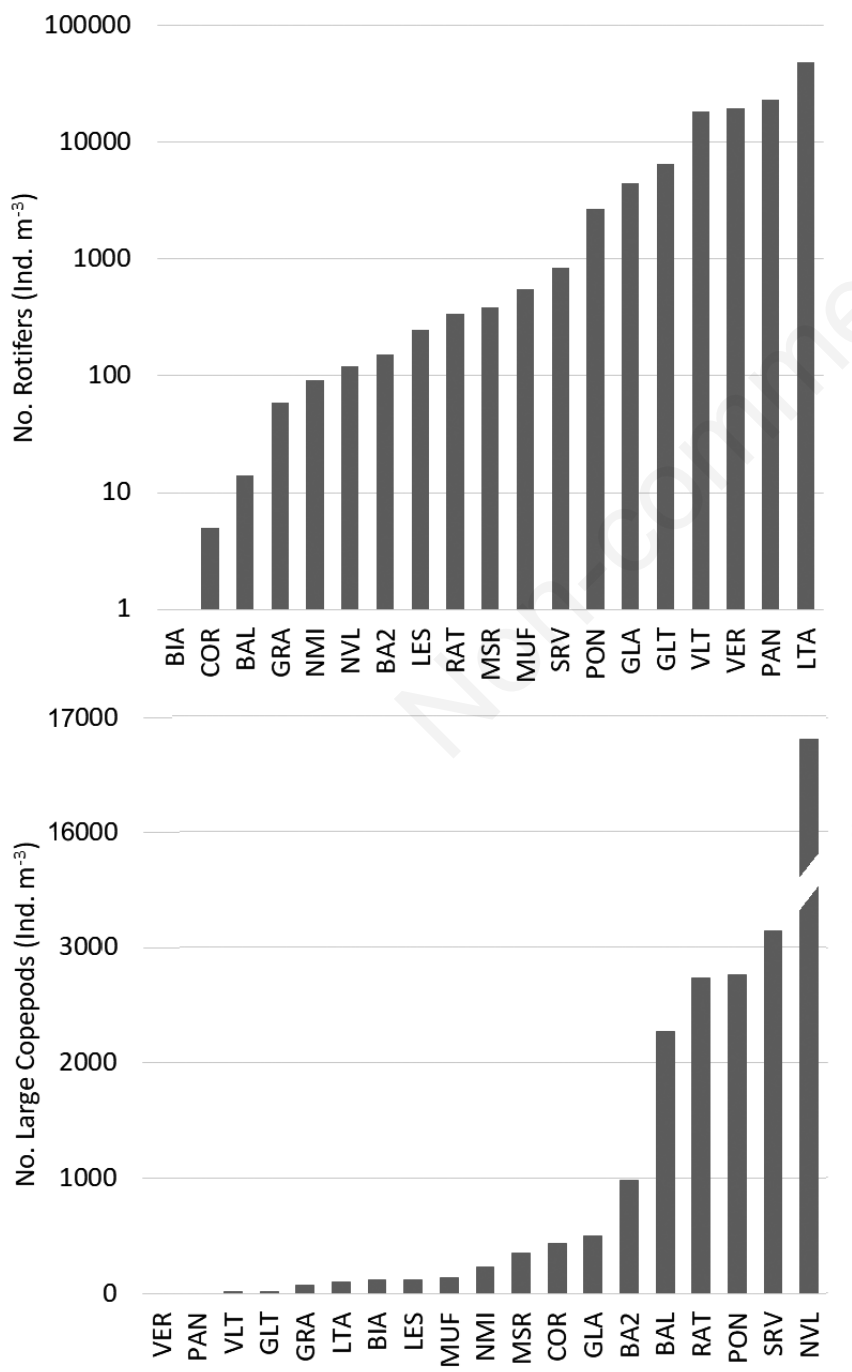

lakes are consistent with what has commonly been observed in other mountain lakes in the Alps. The densities of heterotrophic prokaryotes are in the range of variation of typical alpine lakes, e.g., 0.1-5.8 × $10^{6}$ cells $\mathrm{mL}^{-1}$ (Callieri and Bertoni, 1999; Wille et al., 1999; Tiberti et al., 2014b; Tiberti et al., 2019b). Autotrophic prokaryotes usually increase their relative abundance in oligotrophic lakes (Callieri et al., 2001), but their presence in mountain lakes was considered a rare event as they are sensitive to the high PAR and UV radiation commonly affecting clear mountain lakes (Callieri and Bertoni, 1999; Wille et al., 1999). Interestingly, cytometry also enables the counting of cells with very low fluorescence, as is the case of alpine lakes, being much more powerful than usual microscopic counts. Contrary to this expectation, picocyanobacteria were consistently detected in MANP

14000

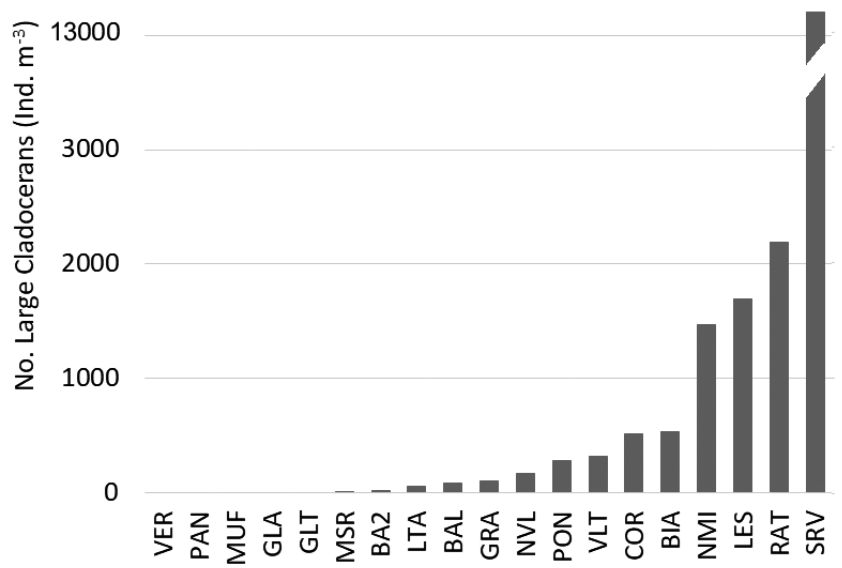

Fig. 5. Zooplankton densities in the lakes of the Mont Avic Natural Park; lake codes from Tab. 1. 
lakes and were sometimes even abundant (e.g., $8.6 \times 10^{3}$ $\mathrm{PE}$ cells $\mathrm{mL}^{-1}$ in L. Cornù and $10 \times 10^{3} \mathrm{PC}$ cell $\mathrm{mL}^{-1}$ in $\mathrm{L}$. de Vernouille) similar to that observed in a neighbouring alpine area (Gran Paradiso National Park; Tiberti et al., 2014b; Tiberti et al., 2019b). However, picocyanobacteria were usually lower in number in the most irradiated part of the water column (surface), confirming their sensitivity to harmful solar radiation (Callieri and Bertoni, 1999) and suggesting that deeper or less transparent lakes, which affect UV ray penetration, may provide better ecological conditions for their survival.

Although phytoplankton densities (EUK) provided in the present paper should be viewed with caution (see "Methods"), EUK densities were in the typical range of variation for mountain lakes (Tiberti et al., 2013) and methodological inaccuracy cannot account for some macroscopic differences among lakes, e.g., L. Mont Glacier presented very low densities of EUK, as well as of all the remaining nano- and pico-plankton groups, which is a likely consequence of the extreme thermal and physical (glacial turbidity) conditions affecting this lake, as noticed elsewhere in the Alps (Sommaruga, 2015).

\section{Aquatic invertebrates}

The mean number of zooplankton taxa per lake (mean $\pm \mathrm{SD}=5.2 \pm 1.5$ ) is comparable or lower to that which is commonly reported in other mountain ranges, e.g., 3.96.4 taxa per lake (Pennak, 1957; Anderson, 1971; Cantonati et al., 2002; Cantonati and Lazzara, 2006). Littoral macroinvertebrate communities are composed of a limited number of taxa and dominated by Chironomidae. These findings are similar to that which has been reported in other alpine lakes and the study area shares the most frequent taxa with other mountain ranges (Miracle 1978). The occurrence of European Daphnia pulicaria in L. Pontonnet is an interesting find; the species is very rare in the Alps and the existence of even a single new population could not only be important for its conservation, but also offer the opportunity to further study their complex phylogenetic history and their interesting adaptations to mountain lake environments (i.e., melanism and obligate parthenogenesis; Bellati et al., 2014). The low taxonomic resolution used for aquatic macroinvertebrates prevents the identification of species with particular conservation value, but previous studies (Novelli et al., 1997; Facchini and Badino, 1998; Sindaco et al., 2008; Evangelista, 2009) highlight the high conservation value of the MANP's aquatic fauna.

Most lakes show scarce zooplankton and macroinvertebrate communities, i.e., they lack some common taxa such as large planktic crustaceans. This could be due to both natural and anthropogenic factors. For example, glacial influence can affect the communities of L. Mont Glacier (Sommaruga 2015) and predation by the native invertebrate Chaoborus sp. could explain the absence of large zooplankton crustaceans from L. Vallet (Neill, 1981). However, introduced fish predation is the most likely explanation of the observed impoverishment of most communities. The impact of fish on macroinvertebrates is usually clearly visible (i.e., many lakes are virtually devoid of non-borrower taxa), but in some cases its impact can also be seen among large zooplankton taxa, (i.e., L. de Vernouille, Panaz, Leita, and Gelato are virtually devoid of large zooplankton). However, in a few cases, the expected effects of fish predation on the invertebrate communities are not clearly observable. This could be attributable to the fact that some a)

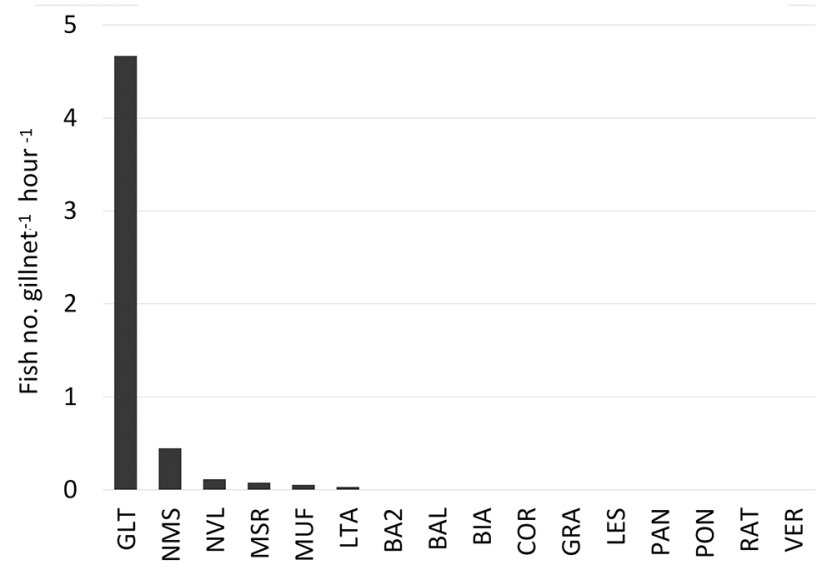

b)

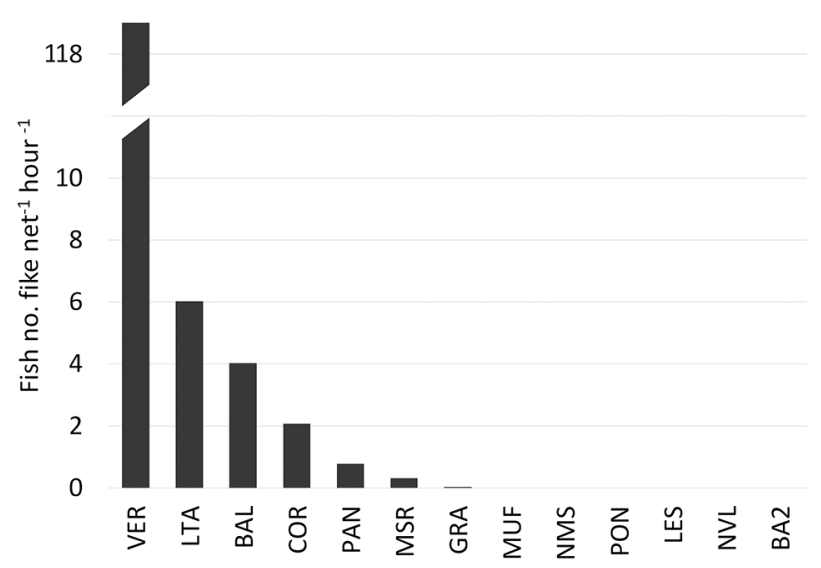

Fig. 6. Density estimates (as Capture Per Unit Effort - CPUE) of Salmonidae (a) and Cyprinidae (b) populations inhabiting the lakes of the Mont Avic Natural Park; lake codes from Tab. 1. 
lakes have very low fish densities. For example, L. Leser, Blanc, and Muffet contain some fish, but large zooplankton species and non-borrower macroinvertebrate taxa are both present, which is typical of pristine invertebrate communities (Knapp et al., 2001). The few fish inhabiting these lakes are most likely residual fish from past stocking campaigns, unable to form a selfsustaining population and insufficient to exert the expected impacts.

\section{Amphibians}

Rana temporaria is present in 12 out of the 19 lakes and its reproduction was only observed in nine lakes. All the lakes of MANP lie below the upper altitudinal limit of $R$. temporaria ( $2799 \mathrm{~m}$ asl. Tiberti and von Hardenberg, 2012), but the harsh microclimatic conditions found at $\mathrm{L}$. Pontonnet, Mont Glacier, and Gelato probably play a role in the ecological exclusion of this species. The absence of reproductive populations of $R$. temporaria from half of the remaining lakes should be therefore attributable to introduced fish predation as already observed in other mountain areas (Knapp et al., 2001; Knapp, 2005; Tiberti and von Hardenberg, 2012; Miró et al., 2018). Despite the impact of introduced fish in many lakes, $R$. temporaria remains fairly common in the MANP area. This is probably due to its ability to breed in a variety of aquatic ecosystems (e.g., ponds, peat bogs) which abound in the MANP and which cannot be colonized by fish.

\section{Local threats}

The Mont Avic Natural Park is a wilderness area dominated by natural environments and completely devoid of stable human settlements. However, all the main local threats potentially affecting high mountain lakes are present in the protected area: 1) two lakes are affected by water exploitation, 2) most lake catchments are affected by livestock grazing and tourists, 3) most lakes have introduced fish fauna. The study lakes are often affected by more than a single threat at a time, which could produce complex interactions among threats, e.g., additive or synergistic interactions (Mirò, 2016).

\section{Water exploitation}

Water level fluctuations associated to water exploitation can affect mountain lake biodiversity, in particular the littoral communities (e.g., macroinvertebrates and littoral vegetation; Gacia and Ballestreros 1998; Krolova et al., 2013; Sutela et al., 2013) and zooplankton (Miró, 2016). However, it must be taken into account that virtually all dammed European mountain lakes have introduced fish fauna due to the ease with which dams can be reached, facilitating fish introductions (Ventura et al., 2017). It could therefore be difficult to distinguish between the co-occurring impacts exerted by water level fluctuations and introduced fish (Miró, 2016). Both the dammed lakes of MANP (L. Miserin, Gran Lac) are devoid of littoral aquatic vegetation, but this is a common feature also found in other natural lakes at similar altitudes. When compared to what can be expected for natural lakes (Tiberti et al., 2014b), the macroinvertebrate communities of both lakes are little diversified and are almost devoid of nonborrower taxa (e.g., benthic Tricoptera, nektonic Coleoptera and Heteroptera). However, easily observed non-borrowers are vulnerable to introduced fish (Knapp et al., 2001) and it is impossible to distinguish if their absence in this case is primarily due to introduced fish or to water exploitation. Despite this, recent research carried out in the Gran Paradiso National Park (a protected area bordering the MANP) indicated that water level fluctuations can worsen the impact of introduced fish on macroinvertebrates (Piacentini, 2019). Water abstraction can also alter the hydrological regimes in the outflowing river, with possible impacts for stream biodiversity and for downstream aquatic habitats. As a consequence, flux regulation along the outflowing river of L. Gran Lac was observed to alter the water level of downstream lakes, i.e., in late summer of 2018 and of 2019, the water level of L. Cornù and Blanc was ca. 1-2 m lower than normal, with possible negative effects for the littoral communities, such as aquatic macrophytes, which are abundant in both lakes.

\section{Organic pollution and livestock}

Livestock dejections in nearshore areas and mountain huts can be point-sources of organic pollutants. The associated nutrient inputs can easily alter the trophic state of oligotrophic mountain lakes (Derlet et al., 2012; Tiberti et al., 2014a), in particular if livestock aggregate around the lakes (Derlet et al., 2012). In addition, livestock can damage important wildlife habitats such as littoral vegetation through trampling and grazing (Buxton, 1991). Therefore, exclusion of livestock from lakeshores and associated wetlands is a desirable management action. Most lakes in the MANP are currently affected to a variable extent by the presence of domestic ungulates in their surroundings, where alpine pastures and high mountain grassland are used to feed herds in summer. Indeed, the summer migration of livestock to the mountain pastures (i.e., Alpine transhumance) is an honoured pastoral tradition all over the Alps as well as in the MANP. However, no major episodes of eutrophication have been observed in the study lakes suggesting that the measures undertaken by the MANP to limit the impacts of livestock grazing, such as exclusion fences (Miserere et al., 1998; Cremonese et al., 2008a; MANP, 2017), have been effective.

Touristic infrastructures are another potential source 
of organic pollutants in otherwise wild mountain regions. In the protected area, touristic infrastructures are represented by a few mountain huts. Three mountain huts are located in close proximity to or inside the catchment of the study lakes (L. Miserin, Blanc and Muffet). Sewage from mountain huts can affect the water quality in downstream aquatic habitats, as sewage treatment may be problematic in high mountain areas due to local climatic conditions, which weaken the effectiveness of the techniques usually adopted to reduce nutrient load (e.g., Imhoff tanks; Piscopo and Caputi, 2015; Muri and Brancelj, 2003). However, as mentioned above, no evident signs of eutrophication were recorded in the protected area, suggesting that organic pollution is not a major ecological issue in the MANP. This said, more frequent monitoring could help in detecting the possible effects of short-term organic pollution events.

\section{Introduced fish}

Mountain lakes are isolated from lower streams by physical barriers that prevent natural colonisation by fish (Miró and Ventura, 2013). However, 76-89\% of the lakes of the MANP have introduced fish fauna. Even if fish introductions involve a substantial percentage of lakes of the Alps and other mountain ranges (Ventura et al., 2017), the percentages of invaded lakes are usually lower than that which was observed in the MANP, e.g., about 50\% in Valle d'Aosta (the administrative region of the MANP; Frezet, 2003) and 35\% in Gran Paradiso National Park (a protected area close to the MANP; Ventura et al., 2017). Fish introduction in once fishless lakes is commonly associated with the decline or disappearance of native invertebrates and amphibians (Knapp et al., 2001; Denoël et al., 2005; Tiberti et al., 2014b; Tiberti, 2018) and can have indirect effects affecting the whole ecosystem (Eby et al., 2006) and its connection with surrounding terrestrial habitats (Epanchin et al., 2010). Our results suggest that the same is occurring in the MANP. This fact, in combination with the high proportion of invaded lakes in the MANP, highlights a challenging conservation issue for this particular protected area. Fish spread in the MANP could be due to fish stocking that took place until 2014 and to permissive fishing regulations adopted by the MANP up to recent times (MANP, 2017). Indeed, besides stocking campaigns, illegal fish translocations by anglers also contribute to the fish invasion of mountain areas (Miró and Ventura, 2013, 2015). The occurrence of many introductions mediated by anglers in the MANP is clearly documented by the widespread distribution of Cyprinidae (i.e., Phoxinus sp. and Telestes muticellus, which were never officially introduced in the MANP, but are used as live bait by anglers), and could possibly explain many discrepancies between the fishery data (Tab. S3) and the observed fish communities. The invasion of mountain regions by minnows is a fast pace process, which has already had dramatic impacts over large mountain areas (Mirò, 2016) and which threatens the residual integrity of alpine lakes at a regional scale (Ventura et al., 2017). The ecological impact of minnows in mountain lakes is less studied than the impact of salmonids (Miró, 2016; Miró et al., 2018), but it is believed to be even stronger than the impact of trout (Miró et al., 2018), exacerbating the problem of introduced fish in the MANP. The widespread presence of minnows in the MANP is likely to be a factor which aggravates the problem of introduced fish in the MANP. Among local threats, alien fish are the most pervasive and impactful problem and should be considered a priority for the conservation of the lakes in the MANP. Fish stocking and fishing have recently been prohibited from all the MANP and from most lakes respectively (excepting L. Miserin, Cornù, Gran Lac; MANP, 2017). These new rules provide a favourable framework for stopping and reversing the fish invasion in the MANP. Stocking bans can determine the extinction of non-reproductive fish populations (e.g., trout in L. Muffet and Leser; Armstrong and Knapp, 2004), but in most cases, fish populations are well established, and, as already experimented in other European and nonEuropean protected areas (Tiberti et al., 2019a; NPS, 2016), only an active eradication campaign could provide the desirable recovery of the lakes.

\section{CONCLUSIONS}

High mountain lakes in the Mount Avic National Park are perhaps the most striking element of the protected area landscape, but they are threatened by water exploitation, organic pollution, and introduced fish. Water quality remains good, despite these multiple local threats; in particular we did not observe any sign of eutrophication clearly attributable to organic pollution from livestock or mountain huts. However, local anthropogenic impacts often affect lake biota. Above all, the presence of alien fish is pervasive in the MANP and removing traces of their impacts should be considered a priority for the protected area. To this end, some essential conservation measures (e.g., fish stocking ban and protection against organic pollutants) have already been taken, but further conservation efforts are needed to restore invaded lakes through fish eradication.

\section{ACKNOWLEDGMENTS}

We thank Giuseppe Bogliani (University of Pavia) for his commitment to research; the Park wardens for their logistic support and hospitality; Eric Wienckowski for his kind help with the bathymetry data; Laura Bohin for her 
careful linguistic revision; Jacopo Todaro, Elena Piacentini, Melissa Maini, and Laura Iacobelli for helping during field work.

Funding for this research was provided by the University of Pavia with the Grant Number 105355 issued to Rocco Tiberti.

Additional funding was provided by the IRSA-CNR of Verbania Pallanza for chemical and flow cytometer analyses.

\section{REFERENCES}

Anderson RS, 1971. Crustacean plankton of 146 alpine and subalpine lakes and ponds in western Canada. J. Fish. Board Can. 28:311-321.

APHA, AWWA, WEF, 2005. Standard Methods for the examination of water and wastewater (Method $4110 \mathrm{~B}$ ). American Public Health Association, Washington.

Armstrong TW, Knapp R, 2004. Response by trout populations in alpine lakes to an experimental halt to stocking. Can. J. Fish. Aquat. Sci. 61:2025-2037

Baxter RM, 1977. Environmental effects of dams and impoundments. Ann. Rev. Ecol. Syst. 8:255-283.

Bellati A, Tiberti R, Cocca W, Galimberti A, Casiraghi M, Bogliani G, Galeotti P, 2014. A dark shell hiding great variability: a molecular insight into the evolution and conservation of melanic Daphnia populations in the Alps. Zool. J. Linn. Soc. 171:697-715.

Boggero A, Zaupa S, Musazzi S, Rogora M, Dumnicka E, Lami A, 2019. Environmental factors as drivers for macroinvertebrate and diatom diversity in Alpine lakes: New insights from the Stelvio National Park (Italy). J. Limnol. https://doi.org/10.4081/jlimnol.2019.1863

Braioni MG, Gelmini D, 1983. Rotiferi Monogononti (Rotatoria: Monogononta). Guide per il riconoscimento delle specie animali delle acque interne italiane. Consiglio Nazionale delle Ricerche, Bologna.

Buxton R, 1991. New Zealand's wetlands: A management guide. Department of Conservation and Environmental Council, Wellington.

Callieri C. Bertoni R, 1999. Organic carbon and microbial food web assemblages in an oligotrophic Alpine lake. J. Limnol. 58:136-143.

Callieri C, Morabito G, Huot Y, Neale PJ, Litchman E, 2001. Photosynthetic response of pico and nanoplanktonic algae to UVB, UVA and PAR in a high mountain lake. Aquat. Sci. 63:286-293.

Callieri C, Amalfitano S, Corno G, Bertoni R, 2016. Grazinginduced Synechococcus microcolony formation: experimental insights from two freshwater phylotypes. FEMS Microbiol. Ecol. 92:fiw154.

Camarero L, Rogora M, Mosello R, Anderson J, Barbieri A, Botev I, et al., 2009 Regionalisation of chemical variability in European mountain lakes. Freshwater Biol. 54:24522469.

Campaioli SP, Ghetti F, Minelli A, 1994. Manuale per il riconoscimento dei macroinvertebrati delle acque dolci italiane. Provincia autonoma di Trento, Trento.
Cantonati M, Tolotti M, Lazzara M, 2002. [I laghi del Parco naturale Adamello-Brenta: ricerche limnologiche su laghi d'alta quota del settore siliceo del Parco].[Book in Italian]. Parco Naturale Adamello Brenta, Trento: 285 pp.

Cantonati M, Lazzara M, 2006. [I laghi di alta montagna del bacino del fiume Avisio (Trentino Orientale) ].[Book in Italian]. MUSE-Museo delle Scienze, Trento: 249 pp.

Conniff R, 2017. Gone fishing. Scientific American 317:42-47.

Council of the European Communities, 1992. Council Directive 92/43/EEC of 21 May 1992 on the conservation of natural habitats and of wild fauna and flora. Official Journal of the European Communities, L206: 7-50.

Council of the European Communities, 1979. Council Directive 1979/409/EEC of the European Parliament and of the Council of 02 April 1979 on the conservation of wild birds. Official Journal of the European Communities, L103: 1-18.

Cremonese E, Galvagno M, Ganis L, Mammoliti Mochet A, Morra Di Cella U, 2008a. [Monitoraggio delle caratteristiche idrochimiche delle torbiere del Parco Naturale Mont Avic e valutazione del potenziale impatto del pascolamento].[Article in Italian]. Revue Valdôtaine d'Histoire Naturelle 61-62:353-366.

Cremonese E, Galvagno M, Ganis L, Mammoliti Mochet A, Morra Di Cella U, 2008b. [Monitoraggio di inquinanti diffusi in ambiente forestale nel Parco Naturale Mont Avic].[Article in Italian]. Revue Valdôtaine d'Histoire Naturelle 61-62:325-339.

Crump ML, Scott NJ, 1994. Visual encounter surveys, p. 84-92. In: W.R. Heyer, M.A. Donnelly, R.W. McDiarmid, L.C. Hayek and M.S. Foster (eds.), Measuring and monitoring biological diversity: Standard methods for amphibians. Smithsonian Institution Press.

de Bernardi R, Giussani G, Lasso-Pedretti E, 1979. Food suitability and availability, demographic parameters and population growth in Daphnia obtusa Kurz under laboratory conditions. In: R. de Bernardi (ed.), Proc. Symp. Biological and Mathematical aspects in population dynamics. Mem. Ist. ital. Idrobiol. Suppl. 37:233-242.

Denoël M, Dzukic G, Kalezic ML, 2005. Effects of widespread fish introductions on paedomorphic newts in Europe. Cons. Biol. 19:162-170.

Derlet RW, Richards JR, Tanaka LL, Hayden C, Ger KA, Goldman CR, 2012. Impact of summer cattle grazing on the Sierra Nevada watershed: aquatic algae and bacteria. J. Environ. Public Health 2012: 760108.

Eby LA, Roach WJ, Crowder LB, Stanford JA, 2006. Effects of stocking-up freshwater food webs. Trends Ecol. Evol. 21:576-584.

Edmondson WT, Winberg GG, 1971. A manual on methods for the assessment of secondary productivity in fresh waters. Blackwell Publ., Oxford.

Einsle U, 1996. Copepoda: Cyclopoida: Genera Cyclops, Megacyclops, Acanthocyclops (No. 595.34 EIN). SPB Academic Pub, Netherlands.

Epanchin PN, Knapp RA, Lawler SP, 2010. Nonnative trout impact an alpine-nesting bird by altering aquatic-insect subsidies. Ecology 91:2406-2415.

Evangelista M, 2009. [Contributo alla conoscenza dei molluschi del Parco Naturale del Monte Avic (Valle d'Aosta, Italia NW)].[Article in Italian]. Revue Valdôtaine d'Histoire 
Naturelle 63:99-124.

Facchini R, Badino G, 1998. [I macroinvertebrati come indicatori di biodiversità delle zone umide del Parco Naturale del Mont Avic].[Article in Italian]. Revue Valdôtaine d'Histoire Naturelle 52:49-77.

Frezet C, 2003. [Catasto dei laghi valdostani].[Book in Italian]. ARPA Valle d'Aosta, Aosta.

Gacia E, Ballesteros E, 1998. Effects of building up a dam in a shallow mountain lake (Baciver, Central Pyrenees). Oecologia aquat. 11:55-66.

Giussani G, de Bernardi R, Mosello R, Origgi I, Ruffoni T, 1986. [Indagine limnologica sui laghi alpini d'alta quota].[Article in Italian]. Doc. Ist. Ital. Idrobiol. 9:1-415.

Hinder B, Baur I, Hanselmann K, Schanz F, 1999. Microbial food web in an oligotrophic high mountain lake (Jöri lake III, Switzerland). J. Limnol. 58:162-168.

ISPRA, 2010. [Note illustrative della Carta geologica d'Italia alla scala 1:50.000. Foglio 091 Châtillon].[In Italian]. Regione Autonoma Valle d'Aosta, Aosta.

Kernan M, Ventura M, Bitušík P, Brancelj A, Clarke G, Velle G, Raddum GG, Stuchlík E, Catalan J, 2009. Regionalisation of remote European mountain lake ecosystems according to their biota: environmental versus geographical patterns. Freshwater Biol. 54:2470-2493.

Knapp RA, 2005. Effects of nonnative fish and habitat characteristics on lentic herpetofauna in Yosemite National Park, USA. Biol. Cons. 121:265-279.

Knapp RA, Matthews KR, Sarnelle O, 2001. Resistance and resilience of alpine lake fauna to fish introductions. Ecol. Monogr. 71:401-421.

Kopáček J, Stuchlík E, Straškrabová V, Pšenáková P, 2000. Factors governing nutrient status of mountain lakes in the Tatra Mountains. Freshwater Biol. 43:369-383.

Krolová M, Č́ž́ková H, Hejzlar J, Poláková S, 2013. Response of littoral macrophytes to water level fluctuations in a storage reservoir. Knowl. Manag. Aquat. Ecosyst. 408:07.

International Energy Agency, 2018. Key world energy statistics 2010. OECD Publishing, Paris.

MANP, 2017. [Piano di gestione territoriale del Parco Naturale Mont Avic].[in Italian] Parco Naturale Mont Avic, Aosta.

Marchetto A, Barbieri A, Mosello R, Tartari GA, 1994. Acidification and weathering processes in high mountain lakes in Southern Alps. Hydrobiologia 274:75-81.

Marchetto A, Mosello R, Psenner R, Bendetta G, Boggero A, Tait D, Tartari GA, 1995. Factors affecting water chemistry of Alpine lakes. Aquat. Sci. 57:81-89.

Margalef R, 1983. Limnologia. Ediciones Omega, Barcellona.

Margaritora F, 1985. [Fauna d'Italia. Cladocera].[Book in Italian]. Edizioni Calderini, Bologna: 399 pp.

Miracle MR, 1978. [Composición específica de las comunidades zooplanctónicas de 153 lagos de los Pirineos y su interés biogeográfico].[Article in Spanish]. Oecologia Aquat. 3:167-191.

Miró A, 2016. Fish as local stressors of Pyrenean high mountain lakes: arrival process and impact on amphibians and other organisms. PhD Thesis, University of Barcelona.

Miró A, Ventura M, 2013. Historical use, fishing management and lake characteristics explain the presence of non-native trout in Pyrenean lakes: Implications for conservation. Biol. Cons. 167:17-24.
Miró A, Ventura M, 2015. Evidence of exotic trout mediated minnow invasion in Pyrenean high mountain lakes. Biol. Invas. 17:791-803.

Miró A, Sabás I, Ventura M, 2018. Large negative effect of nonnative trout and minnows on Pyrenean lake amphibians. Biol. Cons. 218:144-153.

Miserere L, Buffa G, Montacchini F, 1998. [La vegetazione delle zone umide della Valle Chalamy (Alpi Graie)].[Article in Italian]. Revue Valdôtaine d'Histoire Naturelle 52:17-34.

Muri G., Brancelj A, 2003. Seasonal water chemistry variations in three Slovenian mountain lakes. Acta Chimica Slovenica 50:137-148.

Neill WE, 1981. Impact of Chaoborus predation upon the structure and dynamics of a crustacean zooplankton community. Oecologia 48:164-177.

Novelli M, Meregalli M, Della Beffa G, 1997. [Dytiscidae ed Helophoridae (Insecta, Coleoptera) del Parco Naturale del Mont Avic (Valle d'Aosta, Italia)].[Article in Spanish]. Revue Valdôtaine d'Histoire Naturelle 51:59-92.

New York City Department of Environmental Protection, 2010. NYC Green infrastructure plan: A sustainable strategy for clean waterways. New York City Department of Environmental Protection, New York.

NPS, 2013. Restoration of native species in high elevation aquatic ecosystems plan and draft environmental impact statement. Sequoia and Kings Canyon National Parks, Three Rivers.

Pennak RW, 1957. Species Composition of Limnetic Zooplankton Communities. Limnol. Oceanogr. 2:222-232.

Piacentini E, 2019. [Analisi dell'impatto dei bacini idroelettrici sulle comunità di macroinvertebrati bentonici degli ecosistemi acquatici montani].[BSc Thesis in Italian]. University of Pavia.

Piscopo D, Caputo D, 2015. The ecofriendly wastewater treatment at mountain refuges: a short overview of most promising technologies. SMC Magazine 2:117-120.

Rogora M, Massaferro J, Marchetto A, Tartari G, Mosello R, 2008. The water chemistry of some shallow lakes in Northern Patagonian and their nitrogen status in comparison with remote lakes in different regions of the globe. J. Limnol. 67:75-86.

Sindaco R, Di Giá I, Grieco C, 2008. [Le libellule (Insecta: Odonata) del Parco Naturale Mont Avic].[Article in Italian]. Revue Valdôtaine d'Histoire Naturelle 61-62:117-123.

Sommaruga R, 2015. When glaciers and ice sheets melt: consequences for planktonic organisms. J. Plankton Res. 37:509-518.

Stella E, 1984. [Fauna d'Italia. Copepoda: Calanoida (d'acqua dolce)].[Book in Italian]. Edizioni Calderini, Bologna: $101 \mathrm{pp}$.

Sutela T, Aroviita J, Keto A, 2013. Assessing ecological status of regulated lakes with littoral macrophyte, macroinvertebrate and fish assemblages. Ecol. Indicators 24:185-192.

Tiberti R, 2018. Can satellite ponds buffer the impact of introduced fish on newts in a mountain pond network? Aquat. Cons. Freshwat. Marine Ecosyst. 28:457-465.

Tiberti R, von Hardenberg A, 2012. Impact of introduced fish on common frog (Rana temporaria) close to its altitudinal limit in alpine lakes. Amphibia-Reptilia 33:303-307. 
Tiberti R, Tartari G, Marchetto A, 2010. Geomorphology and hydrochemistry of 12 Alpine lakes in the Gran Paradiso National Park, Italy. J. Limnol. 69:242-256.

Tiberti R, Bogliani G, Brighenti S, Iacobuzio R, Liautaud K, Rolla M, von Hardenberg A, Bassano B, 2019a. Recovery of high mountain Alpine lakes after the eradication of introduced brook trout Salvelinus fontinalis using nonchemical methods. Biol. Inv. 21:875-894.

Tiberti R, Nelli L, Tartari G, Wienckowski E, Marchetto A, Rogora M, 2019b. Multi-year trends and determinants of the hydrochemistry of high mountain lakes from the western Italian Alps. Aquat. Sci. 81:54.

Tiberti R, Rogora M, Tartari G, Callieri C, 2014a. Ecological impact of transhumance on the trophic state of alpine lakes in Gran Paradiso National Park. Knowl. Manag. Aquat. Ecosyst. 415:05.

Tiberti R, von Hardenberg A, Bogliani G, 2014b. Ecological impact of introduced fish in high altitude lakes: a case of study from the European Alps. Hydrobiologia 724:1-19.
Toro M, Granados I, Robles S, Montes C, 2006. High mountain lakes of the Central Range (Iberian Peninsula): Regional limnology and environmental changes. Limnetica 25: 217-252.

Ventura M, Tiberti R, Buchaca T, Buñay D, Sabás I, Miró A, 2017. Why should we preserve fishless high mountain lakes?, p. 181-205 In: J. Catalan, J.M. Ninot and M. Aniz (eds.), High mountain conservation in a changing world. Springer.

Wetzel RG, 2001. Limnology: lake and river ecosystems. Academic Press: 1006 pp.

Wille A, Sonntag B, Sattler B, Psenner R, 1999. Abundance, biomass and size structure of the microbial assemblage in the high mountain lake Gossenköllesee (Tyrol, Austria) during the ice-free period. J. Limnol. 58:117-126.

Williamson CE, Dodds W, Kratz TK, Palmer MA, 2008. Lakes and streams as sentinels of environmental change in terrestrial and atmospheric processes. Front. Ecol. Environ. 6:247-254. 